\title{
ВЗАЕМОЗВ'ЯЗОК ТА ВЗАЕМОДІЯ ІМІДЖУ СУДОВОЇ ВЛАДИ УКРАЇНИ І ДОВІРИ ГРОМАДЯН: ПРОБЛЕМИ ТА СПОСОБИ УДОСКОНАЛЕННЯ
}

Шульга $\boldsymbol{A}$. $\boldsymbol{A . , ~ к а н д . ~ н а у к ~} з$ держ. упр, ст., викладач, Інститут державного управління, Чорноморський національний університет ім. Петра Могили, м. Миколаїв, Україна

Ярощук T. О., Новобузький районний суд Миколаївської області - заступник керівника апарату суду. м. Новий Буг, Миколаївської області, Україна

У статті обтрунтовується взаємозв 'язок та взаємодія іміджу судової влади і довіри громадян до неї на сучасному етапі. На початку дослідження визначено поняття «імідж» та «імідж судової влади», а також щзо являє собою довіра в контексті сучасної науки та публічного управління. Наведено різні статистичні дані сочіологічних досліджень, на основі яких зроблено висновок, що рівень довіри громадян до судової влади України занадто низький. Описано Індекс довіри до судової влади. Зазначено, щзо імідж судової влади прямо залежить від рівня довіри громадян до неї. Довіра та імідж судової влади взаємодіють між собою, заради досягнення однієї мети - гідне і справедливе вітчизняне правосуддя. У статті перераховані чинники, які впливають на рівень довіри до судової влади, тим самим погіршуючи ї̈ імідж. Результати окремих соціологічних досліджень свідчать про те, щуо найбільш проблемними факторами в українському правосудді, які впливають на зниження рівня довіри до судової влади є корупџія та людський чинник. Підкреслено, щуо низький рівень довіри до суду є перешкодою для залучення іноземних інвестицій. Наприкінщі статті зазначено, щзо зміна суб'єкта і прочедури призначення суддів та строку їх перебування на посаді кардинальним чином не вплине на рівень корупції в 
системі правосуддя та довіри до судової влади, а також на якість, об'єктивність і незалежність роботи судів. Для покращення існуючої ситуачії в системі вітчизняного правосуддя, насамперед, потрібно змінити ставлення самих суддів до того, щуо вони роблять, їхню свідомість та сприйняття навколишньої реальності. Зроблено висновок, щзо імідж судової влади відіграє неабияку роль не лиме у питанні захисту прав і свобод та відновлення справедливості, а й у питанні економічного зростання всієї держави. Запропоновано напрями підвищення рівня довіри до судової влади та формування ї̈ позитивного іміджу.

Ключові слова: імідж, імідж судової влади, довіра, доступність до правосуддя, корупційність, Індекс довіри до судової влади.

Постановка проблеми у загальному вигляді. Зважаючи на соціальну роль, яку відіграє судова влада в країні, на потребу її якісного й ефективного функціонування задля розбудови демократичної, правової, соціальної держави і громадянського суспільства, а також заради зменшення соціальної напруги в Україні, виникає потреба зруйнувати існуючі негативні стереотипи стосовно діяльності судової влади в цілому і суддів, зокрема, сформувати їх позитивний імідж. Адже від іміджу цих владних інституцій залежить дієвість всього механізму держави, соціальне самопочуття українців та їх впевненість у захищеності закріплених Конституцією України прав і свобод. В умовах сучасної глобалізації та віртуалізації, позитивний імідж судової влади може стати одним із інструментів подолання політико-правової кризи. Підвищення іміджу судової влади сприятиме встановленню законності і правопорядку у суспільстві, закріпленню верховенства права та утвердженню України як дійсно правової держави. Позитивний імідж судової влади є гарантією досягнення мети і реалізації завдань, поставлених державою перед нею, важливим чинником підвищення ефективності роботи ії установ.

Враховуючи зазначене, дослідження даного питання є актуальним і необхідним. Це дасть можливість окреслити перспективи покращення іміджу судової влади, сформулювати напрями формування позитивного іміджу судової влади в Україні на сучасному етапі, 
що, у свою чергу, сприятиме більш ефективній реалізації нашою державою політики європейської інтеграції, розвитку співробітництва $з$ європейськими інституціями.

Аналіз досліджень і публікацій. Багато вітчизняних і зарубіжних дослідників, у тому числі й у сфері державного управління, вивчають й аналізують поняття «імідж», «імідж судової влади», а також методи та механізми його формування. У своїх роботах В. Авер'янов, А. Бернюков, В. Бігун, Ю. Битяк, І. Казанчук, Р. Калюжний, С. Ківалов, Ю. Лобода, Б. Малишев, С. Погребняк, С. Рабінович, В. Смородинський, М. Сірий, О. Стовба, В. Тертишник та інші безпосередньо досліджують проблеми формування позитивного іміджу судової влади, визначають напрямки його вдосконалення. Та враховуючи значну кількість наукових робіт, поза увагою вчених залишаються питання державної політики щодо формування позитивного іміджу суду та напрями іiі реалізації за сучасних умов в Україні. Не приділено достатньої уваги механізмам формування іміджу судової влади у контексті підвищення рівня довіри до них 3 боку громадськості.

Формулювання цілей статті (постановка завдання). Метою цієї статті є обгрунтувати взаємозв'язок та взаємодію іміджу судової влади і довіри громадян та сформулювати способи підвищення рівня довіри громадськості і формування позитивного іміджу судової влади України у контексті реформування судової системи на сучасному етапі.

Виклад основного матеріалу дослідження. Сьогодні поняття «імідж» вживається не лише у вузькоспеціалізованих виданнях, як це було десять років назад, а й доволі часто використовується у діловому спілкуванні, озвучується журналістами, державними діячами, політиками, пересічними громадянами, й, що важливо, вже міцно закріпилося у категоріальному апараті суспільствознавчої галузі знань, у тому числі і в науці державного управління. Вважаємо, що дослідження поняття «позитивний імідж судової влади» слід розпочати із з'ясування змісту самої категорії «імідж».

Феномен іміджу досліджується у багатьох суспільствознавчих науках - філософії, економіці, психології, соціології тощо. I якщо 
спочатку потреба у цілеспрямованому формуванні іміджу відчувалася в економічній сфері, то згодом стало очевидним, що владні структури також потребують створення певного сприйняття суспільством свого образу. Сьогодні термін «імідж» міцно укоренився у вітчизняному політологічному мисленні, позначаючи важливі явища політичного життя суспільства: «імідж політичного лідера», «імідж політичної партії», «імідж держави», «імідж державного службовця», «імідж державної служби» тощо [4, с. 227].

Цікаво, що до XX ст. поняття «імідж» не існувало, проте деякі складові іміджу були вже відомі, зокрема, опис зовнішніх характеристик та їх відповідність внутрішньому світу людини. При цьому малися на увазі не лише позитивні характеристики, а й певні риси, які справляли негативний вплив на оточуючих при першій взаємодії 3 ними. Вважалося, що саме це перше враження й відображає сутність поки ще незнайомої людини [10].

Незважаючи на широту застосування, поняття «імідж» тлумачиться неоднозначно. У дослівному перекладі з англійської мови поняття «імідж» означає імітувати. Вважається, що воно походить від латинського слова image (образ), пов'язаного з латинським словом imitari (імітувати). Найбільш поширене та відоме визначення міститься у Великій енциклопедії, де зазначено, що імідж - це такий, що склався в масовій свідомості і має характер стереотипу емоційно забарвлений образ кого-небудь або чого-небудь. Імідж відображає соціальні очікування певних груп [1, с. 443].

У Словнику української мови слово «імідж» має кілька значень. Це громадська думка, уявлення про когось, щось; репутація, образ спрямований на формування громадської думки чи уявлення про неї [20, с. 78$]$.

Наука державного управління трактує імідж як образ, який цілеспрямовано формується й призначений справляти емоційно-психологічний вплив на певних осіб з метою популяризації, реклами тощо.

Отже, у загальному сенсі іміджем є сформований образ певної особи, явища чи предмета, який підкреслюючи відповідні ціннісні характеристики, покликаний справляти емоційно-психологічний 
вплив на когось 3 певною метою. Відповідно іміджем судової влади $\epsilon$ сформовані у свідомості людини чи всього суспільства цілісні та емоційно забарвлені образи функціонування системи правосуддя та діяльності працівників судових органів, які визначають рівень довіри громадськості до них, та є наслідком цілеспрямованого інформаційно-комунікативного впливу.

Сьогодні Україна впевнено крокує до Свропейського Союзу, зміцнює державність та розвиває економіку. Для успішного досягнення поставлених цілей нашій країні вкрай потрібно сформувати ефективну у своїй діяльності, стійку до зовнішніх факторів, справедливу та законну в процесі винесення рішень систему правосуддя, яка покликана захищати права і свободи, гарантовані Конституцією України. Оскільки саме правосуддя є гарантом законності, справедливості і порядку у суспільстві. Проте, на сьогодні громадяни зневірилися у незалежності та об'єктивності рішень, які ухвалюються суддями.

Довіра людей - це особливе джерело сили інституту правосуддя й одночасно показник ефективності судової влади, що в цілому формує ії позитивний імідж. Адже будь-яка влада без підтримки і довіри населення є не життєздатною. Існування такої ситуації, тим більше довготривале, може спричинити підвищення соціальної напруги в суспільстві. Зміцнення авторитету судів буде сприяти досягненню суспільного визнання і схвалення вітчизняного інституту правосуддя, що проявлятиметься у довірі до нього суспільства i, як наслідок, сприятиме формуванню позитивного іміджу судової влади. Саме тому з-поміж важливих завдань, які поставлені перед сучасною судовою владою, - це здобуття довіри громадян, зміцнення свого авторитету і підвищення соціально-правового статусу в суспільстві, шляхом докорінних змін як з правової точки зору, так і у свідомості суддівського апарату та самих людей.

Результати різних соціологічних опитувань свідчать про значну недовіру народу до публічної влади, зокрема і до судової. Так, наприклад, у грудні 2014 р. Фондом «Демократичні ініціативи імені Ілька Кучеріва» спільно з соціологічною службою Центру Разумкова було проведено опитування населення про його став- 
лення до судової гілки влади. Опитаних було близько двох тисяч осіб віком від 18 років, із яких $81 \%$ виявили недовіру до судової влади [18].

У подальших роках за допомогою проекту «Справедливе правосуддя», яке фінансується Агентством США 3 міжнародного розвитку (USAID), були проведені подібні дослідження, за результатами яких у 2015 р. 79\% опитаних людей зовсім/скоріше не довіряють судовій владі і лише 5\% повністю/скоріше довіряють такій владі [8]; у 2016 р. 69\% опитаних зовсім/скоріше не довіряють судовій владі, 10\% - повністю/скоріше довіряють такій владі (див. Рис. 1) [21].

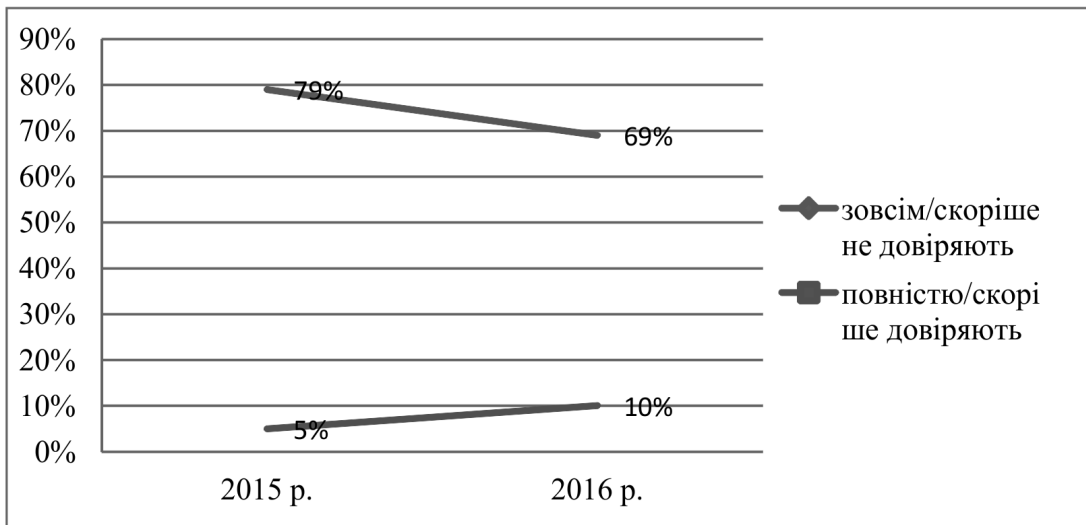

Puc. 1. Рівень довіри людей до судової влади України (2015-2016 pp.)

У 2017 р. Центр Разумкова провів нове соціологічне дослідження, відповідно до якого про свою недовіру до судів (судової системи в цілому) повідомили $80,9 \%$ респондентів, а про довіру $-9,3 \%$. Місцевим судам не довіряють 77,4\% опитаних, довіряють $-11,9 \%$, Верховному Суду України не довіряють 72,0\% громадян, довіряють - 13,1\%, Конституційному Суду України не довіряють 66,8\% громадян, довіряють - 14,9\% (див. Таблиця 1) [24]. 
Рівень довіри до судів та судової системи в цілому

\begin{tabular}{|c|c|c|c|c|c|c|}
\hline & 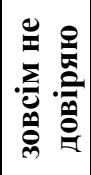 & 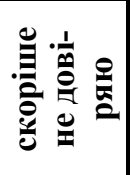 & 送㔀 & 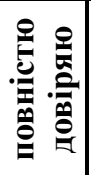 & 尊 & 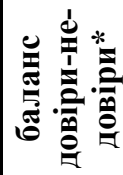 \\
\hline \multicolumn{7}{|l|}{ Місцеві суди } \\
\hline $\begin{array}{l}\text { загальнонаціональне } \\
\text { опитування }\end{array}$ & 44,9 & 32,5 & 10,1 & 1,8 & 10,8 & $-65,5$ \\
\hline $\begin{array}{l}\text { опитування на виході } \\
3 \text { приміщень судів }\end{array}$ & 15,8 & 21,7 & 38,4 & 13,1 & 11,0 & 14,0 \\
\hline \multicolumn{7}{|c|}{ Верховний Суд України } \\
\hline $\begin{array}{l}\text { загальнонаціональне } \\
\text { опитування }\end{array}$ & 42,2 & 29,8 & 10,9 & 2,2 & 15,0 & $-58,9$ \\
\hline $\begin{array}{l}\text { опитування на виході } \\
3 \text { приміщень судів }\end{array}$ & 15,1 & 22,6 & 19,9 & 11,3 & 31,1 & $-6,5$ \\
\hline \multicolumn{7}{|l|}{ Конституційний Суд } \\
\hline $\begin{array}{l}\text { загальнонаціональне } \\
\text { опитування }\end{array}$ & 40,3 & 26,5 & 12,3 & 2,6 & 18,4 & $-51,9$ \\
\hline $\begin{array}{l}\text { опитування на виході } \\
3 \text { приміщень судів }\end{array}$ & 14,7 & 17,9 & 18,8 & 9,8 & 38,8 & $-4,0$ \\
\hline \multicolumn{7}{|l|}{ Антикорупційний суд } \\
\hline $\begin{array}{l}\text { загальнонаціональне } \\
\text { опитування }\end{array}$ & 36,6 & 24,5 & 11,1 & 2,6 & 25,1 & $-47,4$ \\
\hline $\begin{array}{l}\text { опитування на виході } \\
3 \text { приміщень судів }\end{array}$ & - & - & - & - & - & - \\
\hline \multicolumn{7}{|c|}{ Суди (судова система в цілому) } \\
\hline $\begin{array}{l}\text { загальнонаціональне } \\
\text { опитування }\end{array}$ & 47,3 & 33,6 & 8,0 & 1,3 & 9,8 & $-71,6$ \\
\hline $\begin{array}{l}\text { опитування на виході } \\
3 \text { приміщень судів }\end{array}$ & 15,9 & 25,5 & 36,6 & 10,4 & 11,7 & 5,6 \\
\hline
\end{tabular}

*Різниця між часткою тих, хто довіряє, і часткою тих, хто не довіряє 
Крім того, під час даного дослідження представниками Центру Разумкова був проведений невеликий експеримент. Громадянам пропонувалося визначити рівень своєї довіри до Антикорупційного суду, якого на той час ще не існувало, але точилися дискусії навколо його можливого створення. Відповіді опитаних показали, що цьому органу не варто сподіватися на кредит довіри 3 боку населення рівень довіри до ще не створеного органу виявився дуже низьким. Різну ступінь довіри до Антикорупційного суду висловили 13,7\% опитаних, а різну ступінь недовіри - 61,1\%. Такі результати, на наш погляд, можуть свідчити про те, що рішення про довіру чи недовіру до Антикорупційного суду, а також інших судів та судової системи загалом приймаються громадянами швидше 3 політичних міркувань, а не на основі власного досвіду чи інших реальних фактів. 3 високою імовірністю можна припустити, що низький рівень довіри до судів $є$ наслідком вкрай низького рівня довіри до державних органів в цілому (адже не довіряють державному апарату у 2017 р. $80,7 \%$ опитаних) (див. Таблиця 1) [24].

Підтвердженням цього є результати опитування громадян на виході $з$ приміщень судів, які мали безпосередній досвід спілкування із судами. Так, серед громадян, які мають нещодавній досвід спілкування із судами, переважає довіра до судової системи: баланс довіри до судової системи в цілому є позитивним, тобто число опитаних, які довіряють судам (47,0\%), було вищим, ніж число тих, хто судовій системі не довіряє $(41,4 \%)$. Ще більшим є рівень довіри громадян, які контактували із судами до місцевих судів: довіру місцевим судам висловили більшість опитаних - 51,5\%, недовіру - 37,5\%. Дещо нижчим є рівень довіри цих опитаних громадян до Верховного Суду України та Конституційного Суду України, проте ці рівні довіри є значно вищими, ніж серед населення в цілому. До того ж, опитані громадяни швидше за все не мають жодного досвіду спілкування із Верховним та Конституційним судами України, тому близько третини 3 них не змогли визначити свій рівень довіри до цих судів (див. Таблиця 1) [24].

Таким чином, можна узагальнити, що починаючи із 2014 p. за чотири роки в Україні рівень довіри громадян до судової влади 
збільшився на 2,3\%, а рівень недовіри зменшився лише на 0,1\%. При цьому у 2016 р. було значне підвищення рівня довіри громадян до вітчизняної судової влади і водночас відчутне зменшення рівня ïx недовіри, проте вже у 2017 р. ці показники значно змінилися і ми можемо прогнозувати, що в 2018 р. ситуація буде схожою. На наш погляд, це прямо пов'язано із втратою суспільної довіри до діючих політичних лідерів країни та до результативності тих реформ, які вони проводять (див. Рис. 2). Тому, ми вважаємо, що на можливе змінення таких показників рівня довіри/недовіри громадян до судової влади можна сподіватися лише після виборів Президента України та формування нового Уряду країни.

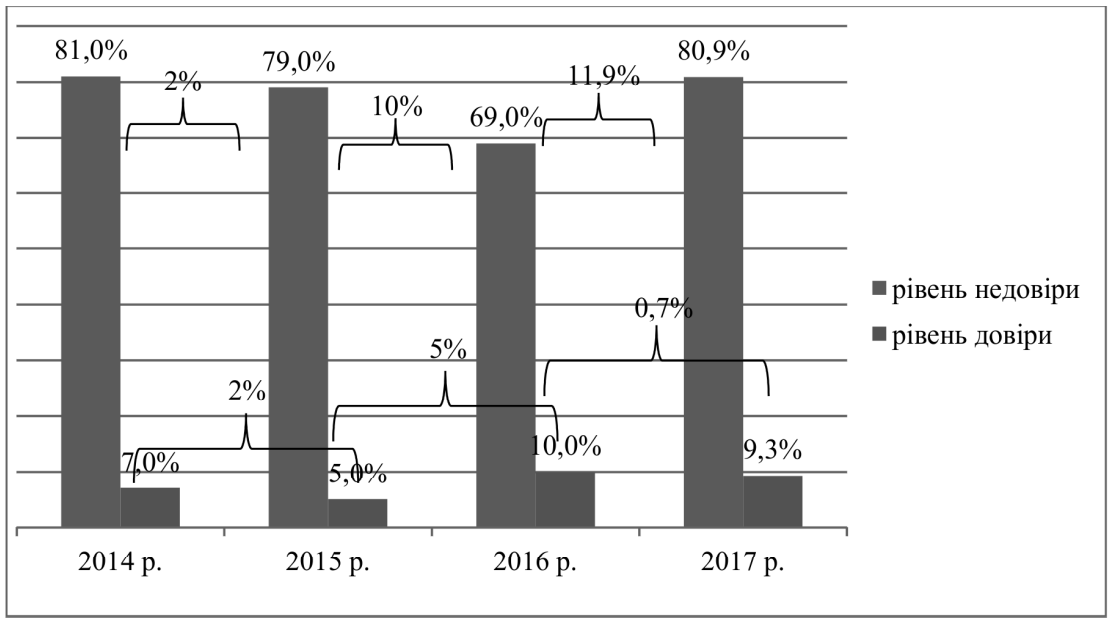

Puc. 2. Рівень довіри громадян до судової влади України (2014-2017рp.)

При цьому у 2017 р. найбільше людей довіряли саме Конституційному Суду України, а найменше - місцевим судам. Проте думка осіб, які безпосередньо перебували у судах є діаметрально протилежною і їх рівень довіри набагато більший (див. Рис. 3). Виходячи iз таких даних робимо висновок, що ні вдосконалення нормативноправової бази та проведення різного роду реформ, зокрема судової, кардинально не змінюють рівень довіри/недовіри громадян до судової влади, що прямим чином впливає на ії імідж. 


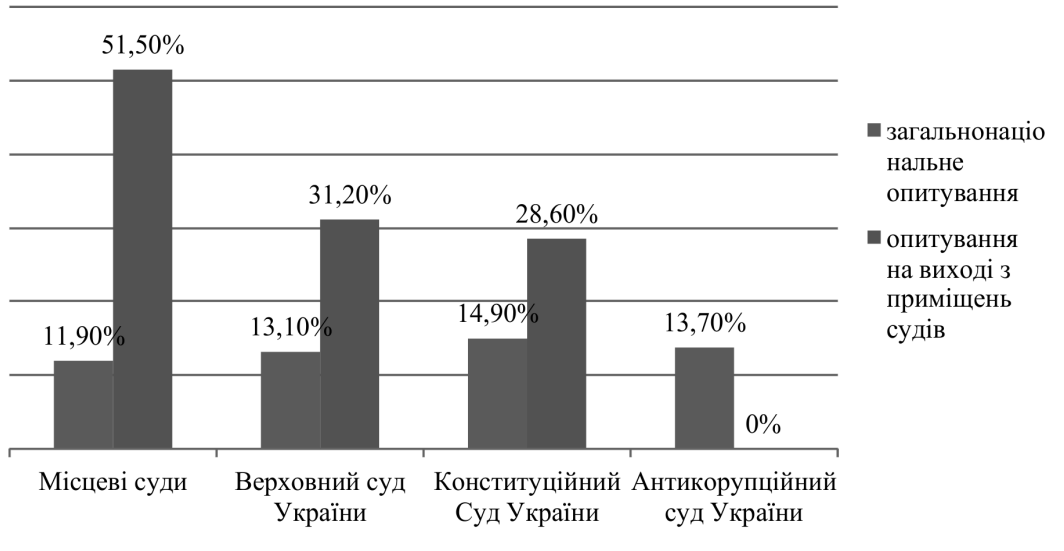

Puc. 3. Рівень довіри громадян до різних судів України у 2017 р.

Та перш ніж вести мову про взаємозв'язок та взаємодію іміджу судової влади і довіри громадян та 3'ясувати причини низького рівня соціальної довіри до українського суду, хотілося б визначити, що являє собою довіра в контексті сучасної науки та публічного управління.

Аналіз наукових джерел свідчить, що в соціально-гуманітарних науках у дослідженні феномену довіри як соціального явища можна виокремити три основні підходи: культурологічний, інституційний і концепцію соціального капіталу. Так, з позицій культурологічного підходу основним джерелом довіри є міжособистісна взаємодія. Згідно з інституційним підходом визначальними у становленні довіри є зовнішні, а не внутрішні чинники (насамперед стосовно політичної довіри та раціонального підгрунтя політичних процесів). Особливої уваги заслуговує третій підхід - концепція соціального капіталу, яку розробили Дж. Коулмен та Р. Патнам. Прихильники цього підходу розглядають довіру як впливовий чинник стабільності системи поряд із нормами та мережами взаємодії. У межах соціальної взаємодії формується як міжособистісна довіра, так і довіра до інститутів суспільства. Певною мірою ця концепція поєднує та 
узагальнює попередні підходи - культурологічний та інституційний $[9$, c. 13].

Сучасні дослідники феномену довіри (Е. Гідденс, П. Штомпка) звертають увагу на те, що в XXI ст. змінилася роль самої довіри. «Тепер вона асоціюється у першу чергу з аналізом тих ризиків, які несе людині взаємодія з іншими людьми або інститутами державами. Подолання невпевненості щодо власної компетентності в окремих питаннях, прагнення перекласти частину своїх повноважень та відповідальності стають основою розвитку довіри між членами окремих груп та по відношенню до держави в цілому» [5, с. 7].

Довіра у загальному сенсі, як вважає Ф. Шандор, - це складне ієрархічне соціальне явище, що відображає певне ціннісне відношення, яке має характер очікування бажаного результату та базується на впевненості у правильності й ефективності дій об'єкта довіри, визнанні його діяльності як відповідної власним інтересам [13].

Якщо говорити про суспільну довіру саме до суду, то, наприклад, Л. Москвич визначає іï як показник ефективності судової влади. Саме тому, на іiі думку, «серед найважливіших завдань, що стоять перед судовою владою в державі, - здобуття довіри людей, зміцнення свого авторитету і підвищення соціального статусу у суспільстві», адже світовий досвід свідчить, що справедливе і незалежне правосуддя й ефективна судова система є там, де судова влада користується довірою людей [6, с. 26].

Варто підкреслити, що питання довіри суспільства до правосуддя в Україні обговорюється не тільки вітчизняними науковцями, політиками та представниками суддівського апарату, а й міжнародними організаціями і комітетами. Так, наприклад, у п. 22 Висновку № 3 (2002) Консультативної ради європейських суддів «Щодо принципів та правил, які регулюють професійну поведінку суддів, зокрема питання етики, несумісної поведінки та безсторонності» зазначено, що відновлення довіри до суду - це суспільна необхідність, адже довіра і повага до судової влади є гарантіями ефективності самої системи правосуддя [22]. Окрім того, свого часу в 2013 р. Свропейська Бізнес Асоціація з метою допомогти у вирішенні питання підвищення рівня довіри до судової влади та формування її пози- 
тивного іміджу в Україні, запропонувала Індекс довіри до судової влади (Судовий Індекс). Цей індекс вимірюється один раз на рік і складається із трьох рівноправних оцінок: 1) оцінка рівня довіри до системи правосуддя з боку керівників компаній-членів Асоціації основних споживачів послуг з юридичного супроводу у судових органах; 2) оцінка ефективності (неупередженості та об'єктивності) судової системи з боку професійного середовища. До цієї аудиторії відносяться «іn house» юристи компаній-членів Асоціації, юристи юридичних/консалтингових компаній, що надають професійні послуги та забезпечують юридичний супровід клієнтів у судах; 3) середньої оцінки 8-ми критеріїв організації та діяльності української судової влади з боку професійного середовища, таких як:

- прозорість судового процесу;

- кваліфікація і професіоналізм суддів;

- відповідність строків прийняття судових рішень законодавчо визначеним термінам;

- якість (обгрунтованість, вмотивованість) судових рішень;

- справедливість судових рішень;

- доступність судових рішень (зручність та відкритість Єдиного державного реєстру судових рішень);

- передбачуваність результатів судового процесу з аналогічних питань;

- незалежність судової системи від органів публічної влади та інших суб' єктів суспільних відносин, фактична доступність судового захисту (реалізація права на судовий захист) [19].

Перша хвиля вимірювання була здійснена в 2013 р., друга - в 2014 р., третя - в грудні 2015 р. - лютому 2016 р. Згідно із судовими індексом: 1) інтегральний показник: 1 хвиля - 2013 р. - 2,02; 2 хвиля - 2014 р. - 2,21; 3 хвиля - 2015 р. - 2,24; 2) довіра до судової системи з боку керівників компаній відповідно за хвилями: 1,72; 1,79; $1,64 ; 3)$ загальна експортна оцінка: неупередженість та об'єктивність судової системи відповідно за хвилями: 1,$96 ; 2,14 ; 2,30 ; 4)$ середня оцінка складових організації та діяльності судової влади відповідно за хвилями: 2,$39 ; 2,70 ; 2,78$ [19]. За цими результатами дослідження можна зробити висновок, що із кожним роком спостерігається незна- 
чне зростання довіри до судової влади та наближення його до нейтрального значення. Однак, ураховуючи те, що об'єктом професійного оцінювання в ці роки були лише адміністративні та господарські суди трьох інстанцій, низка судів залишилася поза оцінюванням, а отже, зазначений судовий індекс не відображав реальний рівень довіри громадян до судової влади України (див. Рис. 4).

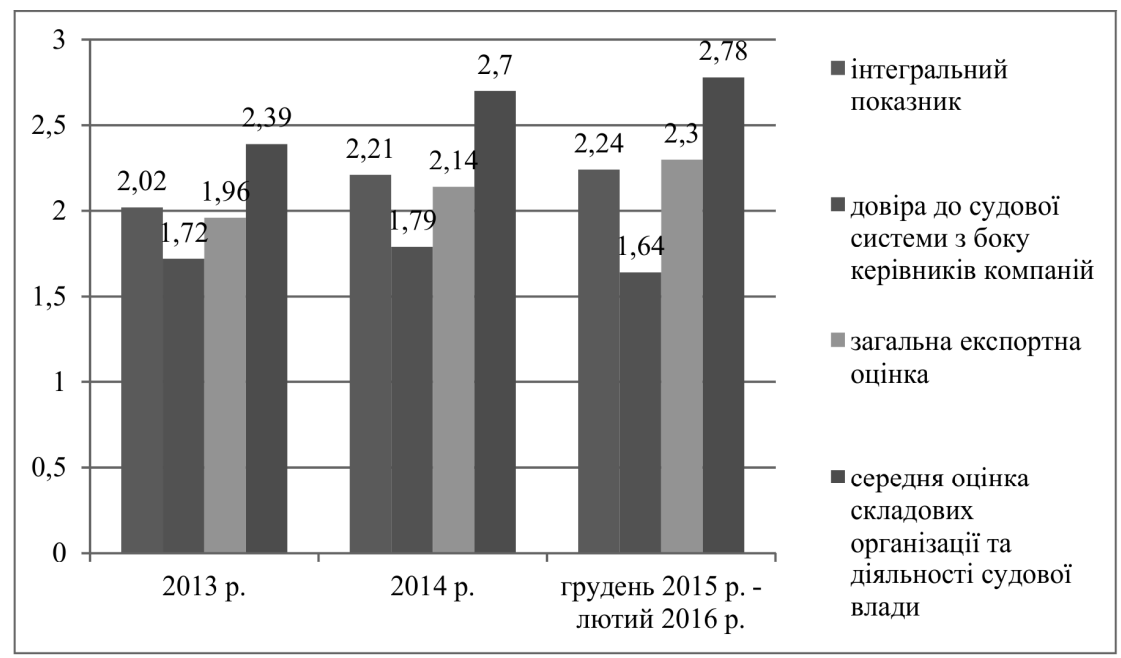

$\boldsymbol{P u c . ~ 4 . ~ І н д е к с ~ д о в і р и ~ д о ~ с у д о в о і ̈ ~ в л а д и ~ ( С у д о в и и ̆ ~ І н д е к с ) ~ ( 2 0 1 3 ~ р . ~ - ~ л ю - ~}$ тий 2016 р.)

Імідж судової влади, як вже зазначалося вище, прямо залежить від рівня довіри громадян до неї - чим вищий рівень довіри, тим більше формується позитивний імідж судової влади, і відповідно навпаки - чим менший позитивний імідж такої влади, тим нижчий рівень довіри громадян до неї. Таким чином, і довіра, і імідж судової влади взаємодіють між собою, заради досягнення однієї мети - гідне і справедливе вітчизняне правосуддя. Але на сьогодні існує ряд чинників, які впливають на рівень довіри до судової влади, тим самим погіршуючи іiі імідж.

Результати окремих соціологічних досліджень свідчать про те, що найбільш проблемним фактором в українському правосудді, 
що впливає на зниження рівня довіри до судової влади є корупція. I якщо в країнах, де рівень корупції в судових органах мінімальний, - наприклад, Данії і Норвегії - кількість людей, які підозрюють суддів у корупції, дорівнює 3\% і 7\% відповідно. То в Україні, навпаки, статистика кримінальних справ, порушених проти суддів за корупційні діяння та діяння, які пов'язані із корупцією, застигла на досить низькому рівні - станом на 2012 р. за даними Генеральної прокуратури України, слідчі порушують проти суддів приблизно по 33 справи на рік [12]. Станом на кінець 2018 р. ситуація практично не змінилася.

Соціологічна служба Центру Разумкова у 2013 р. провела опитування серед українського населення щодо поширення корупції у всіх суспільних сферах діяльності країни. За результатами дослідження визначено, що 47,3\% опитуваних вважають, що в судовій владі все охоплено корупцією, 36,1% - корупція досить поширена, 7,7\% - трапляються окремі випадки корупції і лише 1,8\% вважають, що корупції у вітчизняній системі правосуддя практично немає [15]. Хотілося б одразу ж звернути увагу, що з аналізу підсумків цього опитування є незрозумілим, чи зверталися опитувані до суду особисто, чи їх думка грунтувалася лише на загальному ставленні усього суспільства до судової системи, без їх особистих переконань, тобто вони керувалися думками журналістів та політиків, які займаються популізмом 3 метою підвищити власний рейтинг. Враховуючи це, було паралельно проаналізовано інше соціологічне дослідження із більш конкретними запитаннями та аудиторією - опитування користувачів популярної юридичної газети «Юридична практика». Так, в 2013 р. із 359 опитаних респондентів на запитання «Чи стикалися ви особисто з корупцією в судах?» $65 \%$ відповіли, що стикаються постійно, $16 \%$ - стикаються рідко, а $14 \%$ - не стикаються, але багато про це чули, і лише $5 \%$ опитаних вважають, що корупції в судах не має [7, с. 107]. Вважаємо, що результати даного опитування точніше відображають реальну картину, ніж попереднє, адже більшість читачів даної газети - юристи. Проте таке дослідження не можна назвати народним, а його результати повними. 
У 2015 р. вже 66,0\% опитаних людей вважали, що судова влада в Україні є корумпованою [16]. А в 2017 р. взагалі 80,6\% населення України погодились зі звинуваченням вітчизняних судів у корумпованості, політичній залежності, необ'єктивності та дегуманізації. Не згоді з такою точкою зору лише $6,8 \%$ опитаних. Решта опитаних людей не визначилися із відповіддю. Варто підкреслити, що погоджуються із таким твердженням щодо корумпованості вітчизняної судової системи більшість респондентів, яких опитували на виході 3 приміщень судів, тобто тих, хто мав нещодавній особистий досвід спілкування із працівниками судів та безпосередньо зіткнулися 3 українським правосуддям. Проте серед цих респондентів картина $€$ значно оптимістичнішою: зі звинуваченнями на адресу судів згодні $54,8 \%$ опитаних на виході з судів, не згодні - 15,7\%. Решта опитаних не визначилися із відповіддю (див. Таблиця 2) [24].

Таблиця 2

\section{Рівень згоди/незгоди у звинувачені судової влади України в корумпованості, необ' сктивності та політичній залежності}

\begin{tabular}{|l|c|c|}
\hline & $\begin{array}{c}\text { загальнонаціональ- } \\
\text { не опитування }\end{array}$ & $\begin{array}{c}\text { опитування на вихо- } \\
\text { ді з приміщень судів }\end{array}$ \\
\hline Так, погоджуюся & $80,6 \%$ & $54,8 \%$ \\
\hline Ні, не погоджуюся & $6,8 \%$ & $15,7 \%$ \\
\hline Важко відповісти & $12,6 \%$ & $29,5 \%$ \\
\hline
\end{tabular}

У 2017 р., враховуючи гостру й емоційну дискусію в українському суспільстві щодо високого рівня корупції в судовій владі, було проведено нове соціологічне дослідження. За його результатами було оцінено рівень корумпованості судової влади за п'ятибальною шкалою, де «1» означає повну відсутність корупції, а «5» - що цей орган $є$ повністю корумпованим. Відповідно до цього дослідження українські суди набрали 4,3 бала. Слід зазначити, що трохи кращими є середні оцінки серед тих опитаних, які за останні два роки брали участь у розгляді судових справ - 3,9 бала [24]. 
Як наслідок, з урахуванням вищезазначених показників, маємо таку ситуацію - понад дві третини опитаних людей $(69,0 \%)$ вважають, що на сьогоднішній день громадянин України має більше шансів отримати справедливе судове рішення саме в Європейському суді 3 прав людини ніж в українському суді. Протилежної думки дотримуються 2,7\% опитаних. $12,6 \%$ респондентів вважають, що шанси в обох судах однакові, а решта не визначилися із відповіддю. Серед громадян, які протягом двох останніх років брали участь у розгляді судових справ, ситуація, знов-таки, є дещо оптимістичнішою: серед них 61,1\% вважають, що більше шансів на справедливе рішення в Європейському суді, 7,4\% - що в українському суді, а $18,8 \%$ опитаних вважають, що шанси в обох судах однакові (див. Таблиця 3) [24].

Таблиця 3
Відсоткове співвідношення шансів отримати справедливе судове рішення по страві в українському суді чи в Європейському суді 3 прав людини

\begin{tabular}{|l|c|c|}
\hline & серед усіх опитаних & $\begin{array}{c}\text { серед тих, хто брав } \\
\text { участь у розгляді } \\
\text { судових справ }\end{array}$ \\
\hline В українському суді & $2,7 \%$ & $7,4 \%$ \\
\hline $\begin{array}{l}\text { В Свропейському суді } \\
\text { 3 прав людини }\end{array}$ & $69,0 \%$ & $61,1 \%$ \\
\hline Одинакові шанси & $12,6 \%$ & $18,8 \%$ \\
\hline Важко відповісти & $15,6 \%$ & $12,7 \%$ \\
\hline
\end{tabular}

Підсумовуючи вищевикладені дані, можна зробити висновок, що рівень корупції в судовій владі України з кожним роком збільшується майже у 1,5 рази. Така ситуація $є$ просто ненормальною як і для українських реалій, так і для сприйняття самими європейцями (див. Рис. 5). Оскільки високий рівень корупції за умови низького рівня правової захищеності громадян є негативним фактором, що позначається на загальному рівні правової культури, адже довіра до ISSN 2616-6216. Publ. upr. reg. rozvit. 2019, 3 : 192-218 
суду лежить в основі формування поваги до закону як одного з головних пунктів соціальної угоди і свідчить про те, що судова влада 3 точки зору громадян не є легітимною. Через це довіра до суду має не лише політико-правове, а більш глибоке - культурне значення. Саме тому європейська спільнота вимагала від українських можновладців у найкоротші строки внести суттєві зміни у вітчизняне законодавство стосовно боротьби із корупцією та здійснення державного фінансового контролю, створити відповідні антикорупційні органи, зокрема і Антикорупційний суд. Проте цей процес розтягнувся не на один рік (наприклад, Вищий Антикорупційний суд почав свою роботу лише у червні 2018 р.) і результати від запобігання i боротьби із корупцією наразі є непомітними. Але сподіваємося, що тенденція до зниження рівня корупції в судовій владі і підвищення рівня довіри людей до неї та формування загального позитивного іміджу системи правосуддя в Україні все-таки буде спостерігатися.

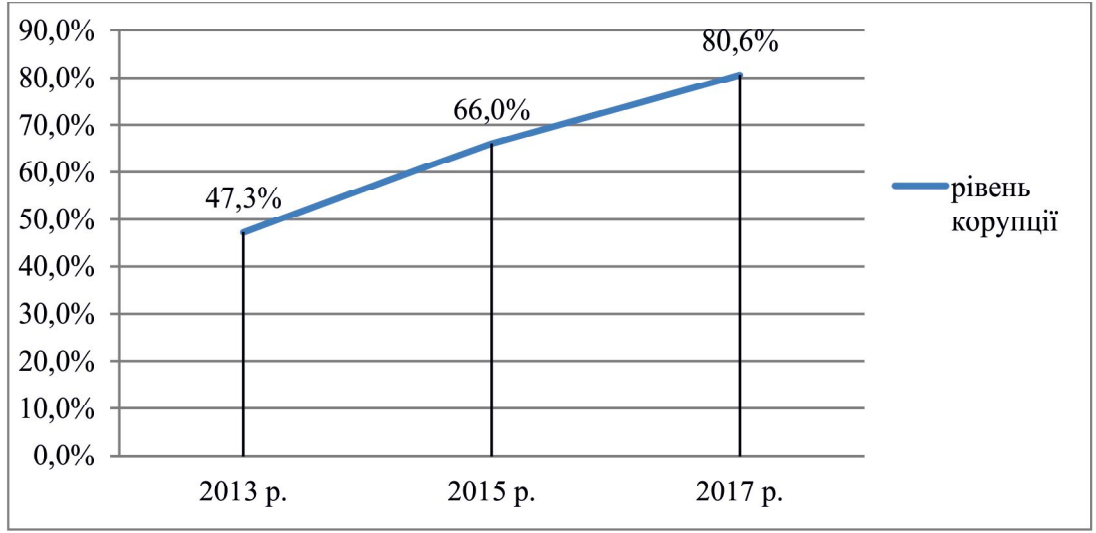

Puc. 5. Рівень корупції в судовій владі в Україні за 2013 р., 2015 р. та $2017 \mathrm{p}$.

Ще один важливий фактор, який впливає на рівень довіри громадян до судової влади - це людський чинник. Не всі судді є людьми із високими моральними цінностями, професіоналами своєї справи, знавцями вітчизняного законодавства та носіями професійної етики 
суддів. Багато 3 них прийшли до суду, використовуючи корупційну складову, з метою особистого збагачення. Частіше за все, вони користуються службовим становищем та зловживають наданими їм законом правами і пільгами, задовольняючи власні потреби чи потреби інших людей.

Сучасне населення України вважає, що будь-який вітчизняний суддя повинен бути професіоналом своєї справи, вміти уміло користуватися нормативно-правовою базою і об'єктивно оцінювати вимоги кожної зі сторін у справі та приймати справедливі і неупереджені рішення. На засіданні Ради з питань судової реформи Президент України Петро Порошенко зазначив, що «сьогодні всім хочеться справедливих, чесних та стабільних правил гри, які буде захищати не корумпований, неупереджений та незалежний суддя. Головне, чого ми маємо добитися, це довіри суспільства до судді, який здійснює правосуддя» [17].

Більшість правознавців, з якими важко не погодитися, схильні до думки, що зміни в судовій системі, які зараз відбуваються в країні, носять «косметичний» характер, а не передбачають кардинальну зміну процесу формування та подальшого функціонування вітчизняної системи правосуддя та ставлення самих представників судової влади до виконання власних повноважень. [11]. Так, у 2015 р. Верховна Рада України прийняла Закон України «Про забезпечення права на справедливий суд» від 12 лютого 2015 р. № 192-VIII, який запровадив конкурсний відбір суддів та систему їх регулярної оцінки різними суб'єктами, в тому числі громадськими організаціями [23].

Згідно із даними Центру Разумкова за 2017 р., більшість громадян (43\%) вважають, що призначення суддів повинно бути у компетенції спеціально створеного для цього, незалежного від законодавчої та виконавчої влади, державного органу, членами якого є судді та представники громадськості без присутності політиків та їх впливів (тільки громада та відповідні фахівці). Інші $28 \%$ опитаних схиляються до того, що судді на відповідні посади повинні обиратися. Крім того, лише $2 \%$ респондентів підтримують ідею призначення суддів пожиттєво, тоді як $41 \%$ - висловлюються за переобрання чи перепризначення суддів кожні 5 років [24]. 
Враховуючи зазначене, вважаємо, що зміна суб'єкта і процедури призначення суддів та строку їх перебування на посаді кардинальним чином не вплине на рівень корупції в системі правосуддя та довіри до судової влади, а також на якість, об'єктивність і незалежність роботи судів. На нашу думку, для покращення існуючої ситуації в системі вітчизняного правосуддя, насамперед, потрібно змінити ставлення самих суддів до того, що вони роблять, їхню свідомість та сприйняття навколишньої реальності. Адже в Україні, доволі часто людина, яка отримала право на зайняття суддівською діяльністю, з першого дня своєї роботи має певні негласні обов'язки перед відповідними особами, які посприяли їй у цьому або можуть певним чином впливати на тривалість здійснення нею своїх повноважень. 3 об'єктивної точки зору, це можна пояснити тим, що призначенням суддів на посади, відповідно до українського законодавства, займається Адміністрація Президента України та Верховна Рада України, інакше кажучи, особи, які займають політичні посади і доволі часто до судочинства не мають ніякого відношення. Тому «фундаментом» функціонування вітчизняної судової системи є прийняття тих чи інших рішень за наказом відповідних зацікавлених осіб (політиків, олігархів, державних управлінців та ін.) $[3$, с. 43].

Дане твердження про діяльність суддів та процесів вирішення справ на підсвідомому рівні засіло у думках громадян. Тому жоден законодавчий акт не здатен зруйнувати таке ставлення, окрім рішучих та кардинальних дій самого суддівського апарату.

Ми погоджуємося 3 висловлюванням голови Первомайського міськрайонного суду Миколаївської області Світлани Сотської: «Судді - це частина українського суспільства, тому ми не можемо та не повинні протиставляти їх суспільству. Судді нашого суду усвідомлюють свою відповідальність перед спільнотою, поважають та розуміють ті вимоги, які ставляться до них в умовах сьогодення. Суди існують не для політиків і не для суддів. Вони існують для всіх. I кожен має бути впевнений, що його справа буде розглянута будь-яким суддею неупереджено, об'єктивно та справедливо. Ми готові змінюватися й прагнемо повернути довіру людей, але й інші 
органи публічної влади мають вживати ефективні і дієві заходи, спрямовані на підвищення авторитету судової влади» [14].

Окрім вищевикладеного варто ще додати, що навіть оптимізація роботи судової влади в Україні прямо впливає на покращення іiі іміджу. Адже запровадження сучасних інноваційних технологій у сфері обслуговування відвідувачів суду та у функціонуванні самої системи правосуддя, злагоджена робота всіх працівників судів та врахування інтересів і потреб суспільства, тісна співпраця із засобами масової інформації дають позитивні результати й забезпечують формування позитивного іміджу судової влади в Україні.

На кінець хотілося б зазначити, що низький рівень довіри до суду є перешкодою для залучення іноземних інвестицій. Хоча для більшості людей ця проблема може здаватися і не надто серйозною у зв'язку з тим, що не один рік народ України не довіряє не лише судовій владі, а й іншим представникам публічної влади, що вже сприймається як норма. Це пов'язано $з$ тим, що налагодженні комунікації і гарні стосунки між суспільством і судами ніколи не були нагальними питаннями в нашій державі. За таких умов і 3 таким відношенням складається враження, що наслідки недовіри до влади є незначними. Проте це зовсім не так. Наслідки існують і вони цілком реально впливають на розвиток суспільних відносин, забезпечення внутрішньої безпеки та безпосередній стан економіки країни.

Для наочного показу вищевикладеного змоделюємо наступну ситуацію. Громадянин Німеччини пан Рудольф хочу інвестувати 50 мільйонів євро в побудову нового заводу з переробки сміття на території Львівської області, оскільки саме цю область в Україні йому радили його помічники. Перед початком інвестування такої значної суми коштів пан Рудольф докладно вивчає та аналізує економічноправову ситуацію в Україні, шукаючи відповіді на головне для себе питання - захист власних інвестицій. Інакше кажучи, інвестування 50 мільйонів євро пана Рудольфа залежить від його впевненості у тому, що він ці кошти не втратить. У контексті питання чи варто довіряти українцям пан Рудольф, у першу чергу, буде аналізувати імідж і авторитет вітчизняних судів. Адже чесний і справедливий 
суд і $є$ запорукою того, що завод 3 переробки сміття, в який пан Рудольф вклав свої кошти, незаконним способом не заберуть [2].

Виходячи 3 цієї ситуації можна стверджувати, що імідж судової влади відіграє неабияку роль не лише у питанні захисту прав $i$ свобод та відновлення справедливості, а й у питанні економічного зростання всієї держави.

Отже, негативний імідж судової влади неминуче породжує недовіру до неї а, значить і до рішень, які приймаються суддями. В основі довіри до судової влади лежить віра кожної людини і суспільства в цілому, в те, що суди добровільно беруть на себе і виконують зобов'язання неупереджено та неухильно захищати їх інтереси. I навпаки, імідж судової влади має забезпечувати судовим рішенням довіру, коли кожна особа, навіть будучи не повною мірою задоволеною ухваленим рішення, однаково вважатиме його правильним, законним і справедливим.

Сприяти формуванню позитивного іміджу судової влади України і підвищенню рівня довіри до неї громадськості покликане сьогочасне реформування судової системи, яке має суттєво оновити «обличчя» вітчизняної системи правосуддя; судді мають бути носіями демократичних та моральних цінностей, усвідомлювати, що від поведінки кожного з них залежить довіра суспільства до всієї судової системи, а в кінцевому результаті й іміджу судової влади. Окрім цього, суди повинні бути відкритими та доступними для громадян незалежно від їх фізичних особливостей, віку чи матеріального становища. Це вимагає усунення зайвих бар'єрів, що можливе за умови вирішення низки важливих питань, а саме: запровадження технологічних інновацій; проведення відкритих судових засідань; зручне розташування суду; належне матеріально-технічне забезпечення; якісне надання судових послуг; подолання інформаційної, фінансової та архітектурної недоступності тощо. Вирішення цих питань значною мірою залежить від розуміння, усвідомлення суддями та іншими працівниками суду того, що їх діяльність спрямована на надання громадянам суспільно важливих послуг.

Висновки. Сьогодні на формування іміджу судової влади України впливають такі важливі фактори як: забезпечення результатив- 
ності діяльності судової влади в інтересах суспільства; прозорість дій і відкритість судової влади до діалогу з громадськістю; підконтрольність діяльності суддів та її висвітлення у засобах масової інформації; ефективна кадрова політика в судових органах; висока якість послуг, що надаються громадянам тощо. У результаті цих чинників створюється або негативний, або позитивний імідж судової влади.

За експертними оцінками Україна належить до країн з дуже низьким рівнем соціальної довіри до суду, що прямо впливає на імідж судової влади в цілому. Більшість населення схиляються до думки, що основним чинником, який негативно впливає на рівень довіри до вітчизняної системи правосуддя, $є$ поширення корупції у великих масштабах в усіх сферах публічного управління, а найбільше - саме в судах. Іншими негативними чинниками $є:$ 1) складна i заплутана судова система; 2) залежність суддів від політиків, олігархів та діючих державних керманичів; 3) прийняття замовлених відповідних судових рішень; 4) групова солідарна відповідальність (кругова порука) у системі вітчизняного правосуддя; 5) низький рівень правової культури, моральності та гуманності значної кількості українських суддів; 6) важкодоступність (у контексті доступу та розуміння) судових процесів для пересічного громадянина тощо.

Враховуючи зазначене, для того, щоб змінити ставлення суспільства до судової влади, необхідні докорінні системні зміни. У зв'язку з цим пропонуємо такі напрями підвищення рівня довіри до судової влади та формування ії позитивного іміджу:

- визначення основних потреб громадян, а в разі необхідності - потреби окремих соціальних груп, і на цій основі - побудова основних засад (принципів) оновленого іміджу судової влади;

- внесення відповідних змін до вітчизняної нормативно-правової бази для забезпечення доступності правосуддя, враховуючи особливості різних категорій населення (вік, рівень освіченості, матеріальний і фізичний стани тощо);

- активне використання представниками судової влади сучасних засобів комунікації у процесі здійснення правосуддя;

- успішне завершення нової чергової судової реформи, особливо у контексті зменшення рівня корупції в судових органах, кар- 
динального оновлення процедури призначення та подальшої роботи суддів та ужорсточення відповідальності представників судової влади.

\section{Стаття надійшла до редакції: 26.12.2018}

\section{INTERCONNECTION AND INTERACTION OF THE IMAGE OF THE JUDICIARY IN UKRAINE AND THE TRUST OF CITIZENS: PROBLEMS AND WAYS OF IMPROVEMENT}

Anastasia Shulga, PhD in Public Administration, Senior Lecturer, Institute of Public Administration, Petro Mohyla Black Sea National University, Mykolaiv, Ukraine

Yaroshchuk Tetyana, magistrate at the Institute of Public Administration, Petro Mohyla Black Sea National University, Mykolaiv, Ukraine

The article deals with the interrelation and interaction of the image of the judiciary and the citizens' trust in it at the present stage. At the beginning of the study, the concept of «image» and «image of the judiciary" is defined, as well as confidence in the context of modern science and public administration. It is noted that today citizens have lost faith in the independence and objectivity of decisions made by domestic judges.

Different statistics of sociological research are presented, on the basis of which it is concluded that the level of citizens' trust in the judiciary of Ukraine is too low. Improving the legal framework and conducting various types of reforms, in particular the judicial system, don't fundamentally change the level of citizens' trust in the judiciary, which directly affects its image. The Index of trust in the judiciary is described.

It is noted that the image of the judiciary directly depends on the level of citizens' confidence in it. The trust and image of the judiciary 
interact with each other, for the sake of achieving one goal-decent and just domestic justice. The article lists the factors that affect the level of trust in the judiciary, thereby worsening its image. The results of individual sociological studies indicate that corruption is the most problematic factor in Ukrainian justice, which affects the level of trust in the judiciary. Another important factor that affects the level of citizens' trust in the judiciary is the human factor. It was emphasized that a low level of trust in court is an obstacle to attracting foreign investments.

At the end of the article it is stated that the change of subject and procedure for the appointment of judges and their term of office will not radically affect the level of corruption in the system of justice and trust in the judiciary, as well as the quality, objectivity and independence of the work of the courts themselves. In order to improve the existing situation in the system of domestic justice, first of all, it is necessary to change the attitude of the judges themselves to what they are doing, their consciousness and perception of the surrounding reality. It is concluded that the image of the judiciary plays an important role not only in the protection of rights and freedoms and the restoration of justice, but also in the question of the economic growth of the entire state. The directions of raising the level of trust in the judiciary and forming its positive image are proposed.

Keywords: image, image of judicial power, trust, access to justice, corruption, index of trust in the judiciary.

\section{Received: 26.12 .2018}

\section{References}

1. Bol'shaya Éntsyklopedyya v 62 tomakh (2006), Tom 18, Yzdatel'stvo TERRA, Moskva [in Russian].

2. Harnyk K.I. (2018), Dovira do sudu ta imidzh sudovoyi vlady: yaki vony s'ohodni? Retrieved from https://censor.net.ua/blogs/3065355/dovra_do_ sudu_ta_mdj_sudovo_vladi_yak_voni_sogodn, 18.05.2018 [in Ukrainian].

3. Harust Y.V., Bondarenko O.S. (2016), Sudova reforma yak holovnyy chynnyk vidnovlennya doviry ukrayins'koho suspil'stva do vlady, Pravo ta innovatsiyi, № 2(14) [in Ukrainian]. 
4. Luts'kyy O.Y. (2013), Osoblyvosti imidzhu derzhavnoyi sluzhby, Naukovyy visnyk Akademiyi munitsypal'noho prava, Vyp. 1 [in Ukrainian].

5. Mishchenko A.B. (2010), Dovira yak skladova lehitymatsiyi vlady v umovakh suchasnoyi demokratiyi, Kyyivs'kyy natsional'nyy universytet imeni Tarasa Shevchenka [in Ukrainian].

6. Moskvych L.M. (2011), Suspil'na dovira do sudu yak pokaznyk efektyvnosti sudovoyi vlady, Visnyk Verkhovnoho Sudu Ukrayiny, № 2(126) [in Ukrainian].

7. Mykhaylychenko D.H. (2014), Kvalifikatsiya oderzhannya khabara sluzhbovoyu osoboyu, yaka zaymaye vidpovidal'ne chy osoblyvo vidpovidal'ne stanovyshche, Aktual'ni problemy polityky, Vyp. 37 [in Ukrainian].

8. Natsional'ne opytuvannya hromads'koyi dumky shchodo demokratychnykh ta ekonomichnykh reform, sudovoyi reformy ta shchodo vprovadzhennya Zakonu Ukrayiny «Pro ochyshchennya vlady» (2015), Proekt USAID «Spravedlyve pravosuddya», Retrieved from http://www.fair.org.ua/ content/library_doc/2015_FAIR_July_Public_Survey_Lustration_UKR.pdf, 12.12.2018 [in Ukrainian].

9. Novoselova V.K. (2016), Indeks doviry do sudovoyi vlady v Ukrayini: ponyattya y kryteriyi, Natsional'nyy yurydychnyy zhurnal: teoriya i praktyka, № 1 [in Ukrainian].

10. Pashchenko Y.I. (2013), Protses formuvannya imidzhu politychnoho lidera u ramkakh vyborchykh realiy Ukrayiny 2010 roku, Visnyk Natsional'noho universytetu "Yurydychna akademiya Ukrayiny imeni Yaroslava Mudroho», Retrieved from https://cyberleninka.ru/article/n/istoricheskoe-stanovleniefenomena-imidzh-politicheskogo-lidera, 19.12.2018 [in Ukrainian].

11. Radchuk O.V. (2015), Sudova revolyutsiya: chy vdast'sya vidnovyty doviru do sluzhyteliv Femidy?, Analitychnyy portal «Slovo i dilo», Retrieved from http://www.slovoidilo.ua/2015/09/24/stattja/polityka/sudova-revolyucziya-chyvdastsya-vidnovyty-doviru-do-sluzhyteliv-femidy, 24.09.2018 [in Ukrainian].

12. Riven' doviry do ukrayins'kykh sudiv nablyzhayet'sya do absolyutnoho minimumu (2012), Korespondent, Retrieved from https://ua.korrespondent.net/ ukraine/politics/1405614-korrespondent-riven-doviri-do-ukrayinskih-sudivnablizhaetsya-do-absolyutnogo-minimumu, 12.10.2018 [in Ukrainian].

13. Shandor F.I. (2011), Lehitymatsiya vlady: i dovira i tolerantnist' yak chynnyky sotsial'noho buttya, Osvita rehionu, № 14, Retrieved from http:// social-science.com.ua/article/650, 12.12.2018 [in Ukrainian].

14. Sot·s'ka S.O. (2015), Sud, vidkrytyy do lyudey, Retrieved from http:// pervomausk.info/news/12829, 10.12.2018 [in Ukrainian]. 
15. Sotsial'ne opytuvannya Tsentru Razumkova (2014), Tsentr Razumkova, Retrieved from http://www.razumkov.org.ua/ukr/poll.php?poll_ id $=516,15.11 .2018$ [in Ukrainian].

16. Stan koruptsiyiv Ukrayini: porivnyal'nyy analizzahal'nonatsional'nykh doslidzhen': 2007, 2009, 2011 ta 2015 (2015), Kyyivs'kyy mizhnarodnyy instytut sotsiolohiyi, Retrieved from https://nazk.gov.ua/sites/default/files/docs/ nazk_files/doslidzhennya/34.pdf, 13.11.2018 [in Ukrainian].

17. Sudova reforma vidnovyt' doviru suspil'stva do suddiv (2015), Radio Svoboda, Retrieved from http://www.radiosvoboda.org/media/video/27040058. html, 20.12.2018 [in Ukrainian].

18. Sudova reforma. Hromads'ka dumka naselennya (2014), Fond Demokratychni initsiatyvy imeni Il'ka Kucheriva, Retrieved from http://www. dif.org.ua/ua/publications/press-relizy/sudova-reforpertiv-.htm, 13.12.2018 [in Ukrainian].

19. Sudovyy Indeks Asotsiatsiyi (2016), Yevropeys'ka Biznes Asotsiatsiya, Retrieved from https://eba.com.ua/about-eba/indices/court-index, 28.11.2018 [in Ukrainian].

20. Velykyy tlumachnyy slovnyk suchasnoyi ukrayins'koyi movy (2001), Vydavnytstvo VTF «Perun», Kyyiv ta Irpin' [in Ukrainian].

21. Vseukrayins'ke opytuvannya hromadyan - stavlennya do demokratychnykh zmin u politychniy ta suspil'niy sferakh, sudovoyi reformy ta protsesu ochyshchennya vlady v Ukrayini (2016), Proekt USAID «Spravedlyve pravosuddya», Retrieved from http://www.fair.org.ua/content/library_doc/fair gfk_ukr.pdf., 25.11.2018 [in Ukrainian].

22. Vysnovok № 3 (2002) Konsul’tatyvnoyi rady yevropeys’kykh suddiv do uvahy Komitetu Ministriv Rady Yevropy shchodo pryntsypiv ta pravyl, yaki rehulyuyut' profesiynu povedinku suddiv, zokrema, pytannya etyky, nesumisnoyi povedinky ta bezstoronnosti, Retrieved from http://www.arbitr. gov.ua/files/pages/\%D0\%92\%D0\%B8\%D1\%81\%D0\%BD\%D0\%BE\%D0\%B2 $\% \mathrm{D} 0 \% \mathrm{BE} \% \mathrm{D} 0 \% \mathrm{BA} \% 20 \% \mathrm{E} 2 \% 84 \% 96 \% 203$.pdf, 15.12 .2018 [in Ukrainian].

23. Zakon Ukrayiny «Pro zabezpechennya prava na spravedlyvyy sud» vid 12 lyutoho 2015 r. № 192-VIII, Vidomosti Verkhovnoyi Rady Ukrayiny, 2015, № 18, 19-20, St. 132 [in Ukrainian].

24. Zvit za rezul'tatamy sotsiolohichnoho doslidzhennya «Stavlennya hromadyan Ukrayiny do sudovoyi systemy» (2017), Tsentr Razumkova, Retrieved from http://rsu.gov.ua/uploads/article/final-report-survey-e07f150174. pdf, 11.12.2018 [in Ukrainian]. 


\section{Відомості про авторів / Information about the Authors}

Шульга Анастасія Алімівна: Чорноморський національний університет імені Петра Могили: вул. 68 Десантників 10, Миколаїв, 54003, Україна

Shulga Anastasia: Petro Mohyla Black Sea National University: 68 Desantnykiv str. 10, Mykolaiv, 54003, Ukraine.

\section{ORCID.ORG/0000-0002-8528-8722}

\section{E-mail: ondain2009@ukr.net}

Ярощук Тетяна Олександрівна: Новобузький районний суд Миколаївської області - заступник керівника апарату суду. м. Новий Буг, Миколаївської області, 55600, Україна

Yaroshchuk Tetyana: Novobugsky District Court of Mykolaiv region Deputy Head of the Court. m. New Bug, Mykolaiv region, 55600, Ukraine. 